\title{
Atypical Meningioma in the Medulla Oblongata Parenchyma
}

Qiushi Xu

Dalian Medical University

Ziang Pan

Dalian Medical University

Meidan Hou

Dalian Medical University

Fang Peng ( $\nabla$ pengfanglisa@163.com )

Dalian Medical University

\section{Case Report}

Keywords: Meningioma, Medulla oblongata, Case report

Posted Date: November 23rd, 2020

DOI: https://doi.org/10.21203/rs.3.rs-112925/v1

License: @ (i) This work is licensed under a Creative Commons Attribution 4.0 International License. Read Full License 


\section{Abstract}

Background: Glioma is the most common tumor occurring in the brainstem. A primary intraparenchymal meningioma located in the brainstem without dura attachment is rare. Meanwhile, atypical meningiomas that occur in the medulla oblongata parenchyma, and without dura coverage, are extremely rare. In this study, we report the first case of atypical meningioma in the medulla oblongata parenchyma and review the existing literature.

Case presentation: A 38-year-old female was admitted at our hospital with a 2-week history of progressive neck and occipital pain. Magnetic resonance imaging revealed a presence of a $1.5 \times 0.9 \mathrm{~cm}$ mass lesion, located in the left side of the medulla oblongata, which was hypointense on T1-weighted and hyperintense on T2-weighted images, and with inhomogeneous enhancement following gadolinium-diethylenet-riamine pentaacetic acid (Gd-DTPA) administration. The initial preoperative diagnosis was glioma or angioblastoma. The patient underwent a total surgical resection of the left medulla oblongata tumor and the histopathological examination indicated that the lesion was an atypical meningioma. The patient returned to normal life after surgery.

Conclusions: Although glioma is the most common tumor occurring in the brainstem parenchyma, the possibility of meningioma cannot be ruled out in this area.

\section{Introduction}

Glioma is the most common tumor occurring in the brainstem [1]. However, primary meningiomas that occur subcortically in the brainstem, and without dura coverage, are rare. Meanwhile, atypical meningiomas that occur in the medulla oblongata parenchyma, and without dura coverage, are extremely rare. Our review of the literature revealed fifteen well-described cases of complete intraparenchymal meningioma. These mostly affected the cerebral hemispheres of patients aged between 14-month and 66-year-old [2-16]. Only one case occurred in the medulla oblongata parenchyma, and was identified as meningothelial meningioma in 1985. In this study, we report the first case of atypical meningioma in the medulla oblongata parenchyma and review the existing literature.

\section{Case Presentation}

\section{Clinical history}

A 38-year-old female presented with a 2-week history of progressive neck and occipital pain. In the pre-admission week, the patient experienced increased pain, vomiting, dizziness and discomfort, coughing after swallowing and drinking water, and voice hoarseness. In addition to the later symptoms, the physical examination revealed that the patient was conscious and able to reasonably answer questions. The pupil was $3.0 \mathrm{~mm}$ on both sides, reflecting light sensitivity. There were no central face paralysis, tongue paralysis and facial numbness. The neck stiffness suggested weak positivity, and the left limb muscle strength was grade 4 with normal muscle tension. The left side instead of right side of the Babinski sign was positive. Magnetic resonance (MR) imaging revealed the existence of a $1.5 \times 0.9 \mathrm{~cm}$ mass lesion, located in the left side of the medulla oblongata, that was hypointense on T1-weighted and hyperintense on T2weighted images (Fig. 1A-B). The mass also showed an inhomogeneous enhancement following gadolinium-diethylenet-riamine pentaacetic acid (Gd-DTPA) administration (Fig. 1C-E). The initial preoperative diagnosis indicated glioma and angioblastoma.

Under general anesthesia, the patient underwent a total surgical resection of the left medulla oblongata tumor using the far-left lateral approach. The tumor had a rotting fish meat appearance and was completely buried in the brain parenchyma with no dura mater around the tumor. The tumor was completely removed, and the operative course was uneventful.

\section{Pathologic findings}

The histological examination revealed the presence of epithelial-like polygonal tumor cells, with eosinophilic cytoplasm. The tumor cells were actively proliferating, with moderate atypia, some necrosis and pathological mitosis. The boundaries of the tumor cells were crowded and unclear (Fig. 2A-C). The immunohistochemistry profile showed positivity for Vimentin, epithelial membrane antigen (EMA) and PR (Fig. 2D-F), but negativity for cyto-keratin (CK), the glial fibrillary acidic protein (GFAP), Oligo-2, S-100, NSE, NeuN, CD34, CD31, CD56 and the PAX-8 protein (Fig. 2H-L). The Ki-67 proliferative index was approximately $30 \%$ (Fig. $2 \mathrm{G}$ ). These findings were consistent with atypical meningioma (World Health Organization grade $\mathbb{Z}$ ).

The most common tumor, without dura in the brainstem parenchyma, was glioma, but immunohistochemical findings showed that the tumor cells GFAP and Oligo-2 were negative in this case. On the other hand, neurogenic tumors should also be considered from the perspective of imaging, and angioblastoma should not be excluded. So we tested S-100, NSE, NeuN, CD34, CD31. The results were also negative. In addition, we considered the possibility of neuroendocrine tumor and metastatic carcinoma (transparence renal cell carcinoma, grade $₫$ ), while CD56, CK and PAX-8 were all negative. The immunohistochemistry profile showed positivity for Vimentin, EMA and PR. Eventually we favored the diagnosis of meningioma based on the morphological and immunohistochemical findings.

There was no evidence of tumor recurrence on postoperative MR imaging at the patient's 3-month follow-up visit (Fig. 3A-E). The patient's physical condition significantly improved after ten months follow-up period. She can independently eat, swallow, and normally communicate with others, without hoarseness.

\section{Discussion}

After literature review [2-21], we found fifteen well-described cases of complete intraparenchymal meningioma [Table 1]. The male-to-female ratio was 11:4 and their age ranged from 14-month to 66-year-old, and the median age was 15-year-old. It is more frequently encountered in children and adolescent, with most of lesions affecting the cerebral hemispheres. We found only three primary meningioma in the parenchyma of the posterior fossa and without dural 
attachment. There was only one case occurred in the medulla oblongata in all of the English-language literatures, which was a meningothelial meningioma in 1985 and our case is the first atypical meningioma in the medulla oblongata parenchyma. The patient is a 38-year-old female, who is elder than most of the patients, but younger than common sites meningioma patients.

Meningiomas that are usually attached to the dura, are thought to originate from the (meningothelial) arachnoid cells or arachnoid cap cells [2, 11]. Nevertheless, the pathogenesis of primary intraparenchymal meningiomas is unclear. It was proposed that some arachnoid cap cells were located in the arachnoid or cerebral pia mater and far from the dura mater [2]. However, the cause of meningiomas in the intraparenchymal posterior fossa is unknown. This may be due to arachnoid cells of the piamater, which enter the brain along with perforating blood vessels, or due to an ectopy of the arachnoid cells that are localized in the white matter, or due to arachnoid cells that rest during the brain development migratory progress [5, 9]. As one gets older, arachnoid cells proliferate and form tumors.

In general, gliomas are most common tumor in the brainstem [1]. But there are no typical radiological features of gliomas in this case. During the surgery, the tumor was observed in the medulla oblongata parenchyma, without dura mater around the tumor. Thus, it was difficult to distinguish meningioma from glioma at the preoperative and intraoperative stage.

The postoperative immunohistochemical staining showed negativity for GFAP, Oligo-2, S-100, NSE, CD34, CD31 and PAX8. Gliomas, neurogenic tumors, angiogenic tumors, and high-grade clear cell carcinoma of kidney origin were excluded. Positivity for Vimentin, EMA and PR proteins confirmed the meningioma of the lesions. According to the obvious cell atypia, the high Ki-67 index, and pathological mitosis, the final diagnosis indicated an atypical meningioma in the medulla oblongata parenchyma.

Most meningiomas can be completely excised by surgery [22]. Some patients received postoperative radiotherapy due to the atypical characteristic of the meningioma and residual tumor growth $[2,5]$. Whether atypical meningiomas patients need postoperative radiation therapy, remains controversial. Some studies showed that there was no significant benefit for progression-free survival or overall survival after adjuvant radiotherapy for atypical meningiomas [2325]. Compared with benign meningioma, atypical meningioma is a tumor with a relatively poor prognosis and with a recurrence rate of approximatively $29 \%-52 \%$ [22].The main recurrence factors that affect are related to the extent of the surgical resection, the tumor site and invasion extent, the vital adjacent structure of the tumor and the surgeon skills $[22,25]$. In this case, the tumor localized in the medulla oblongata parenchyma of the brainstem. The tumor was completely removed. Postoperatively, the patient refused radiotherapy.

\section{Conclusions}

Glioma is the most common tumor occurring in the brainstem [1]. In this case, a 38-year-old female patient was diagnosed with atypical meningiomas that localized in the medulla oblongata parenchyma of the brainstem. The lesion preoperative diagnosis was difficult due to the atypical imaging features. This study is the first to report atypical meningiomas in the medulla oblongata parenchyma, which will help clinicians and imaging doctors to better understand this disease and pay more attention to the differential diagnosis of tumors in the brainstem parenchyma. The possibility of meningioma cannot be ruled out in this area. A complete resection is important for favorable prognosis, but long-term follow-up is necessary.

\section{Abbreviations}

MR: Magnetic resonance; Gd-DTPA: Gadolinium-diethylenet-riamine pentaacetic acid; EMA: Epithelial membrane antigen; PR: Progesterone protein; CK: cytokeratin; GFAP: Glial fibrillary acidic protein; NSE: Neuronal enolase

\section{Declarations}

\section{Acknowledgements}

Not applicable.

\section{Authors' contributions}

XQ designed the study, screened and analyzed radiographic images from the literature. PZ was responsible for collection of clinical data. HM provided the MRI imaging Figures. PF made the pathologic diagnosis of the primary tumor and wrote the original manuscript. All authors read and approved the final manuscript.

\section{Funding}

There is no any financial support for this work.

\section{Availability of data and materials}

All data generated or analyzed during this study are included in this published article.

\section{Ethics approval and consent to participate}

Not applicable.

\section{Consent for publication}


Informed consent for publication was obtained from the patient's family.

\section{Competing interests}

The authors declare that they have no competing interests.

\section{References}

1. Eisele SC, Reardon DA. Adult brainstem gliomas. Cancer 2016;122:2799-809.

2. Zhang J, Chi LY, Meng B, Li F, Zhu SG. Meningioma without dural attachment: case report, classification, and review of the literature. Surg Neurol 2007;67:535-9.

3. Reynolds MR, Boland MR, Arias EJ, Farrell M, Javadpour M, Caird J. Intraparenchymal meningioma within the basal ganglia of a child: A case report. Br J Neurosurg 2016;30:360-2.

4. Jiang XB, Ke C, Han ZA, Lin SH, Mou YG, Luo RZ, et al. Intraparenchymal papillary meningioma of brainstem: case report and literature review. World J Surg Oncol 2012;10:10.

5. Liu X, Zhang Y, Zhang S, Tao C, Ju Y. Intraparenchymal Atypical Meningioma in Basal Ganglia Region in a Child: Case Report and Literature Review. J Korean Neurosurg Soc 2018;61:120-26.

6. Karadereler S, Aker F, Berkman Z. Intraparenchymal meningioma in a child. Case report and review of the literature. J Neurosurg 2004;101:112-5.

7. Shimbo D, Kato T, Takeda M, Ikeda H. Intraparenchymal meningioma in a child. Neurol Med Chir (Tokyo) 2011;51:793-7.

8. Werbrouck C, Florin D, Van Holsbeeck B, Laridon E, De Weweire M, Marrannes J. Intraparenchymal meningioma in a child. JBR-BTR 2014;97:46.

9. Legius E, Vles JS, Casaer P, Plets C, Dom R. Intraparenchymal meningioma in a 14-month-old infant: case report. Brain Dev 1985;7:622-4.

10. Tekkök IH, Cinel L, Zorludemir S. Intraparenchymal meningioma. J Clin Neurosci 2005;12:605-8.

11. Jadik S, Stan AC, Dietrich U, Pietilä TA, Elsharkawy AE. Intraparenchymal meningioma mimicking cavernous malformation: a case report and review of the literature. J Med Case Rep 2014;8:467.

12. Zhao SL, Li Y, Tian XY, Li Z, Huang Q, Li B. Intraparenchymal cystic chordoid meningioma: a case report and review of the literature. Neuropathology 2011;31:648-53.

13. Mut M, Söylemezoğlu F, Firat MM, Palaoğlu S. Intraparenchymal meningioma originating from underlying meningioangiomatosis. Case report and review of the literature. J Neurosurg 2000;92:706-10.

14. Matsuda R, Shida Y, Nakamura M. Intraparenchymal Meningioma in the Basal Ganglia. World Neurosurg 2019;128:186-88.

15. Sakaki S, Ohsugi T, Chaki T, Shiraishi M, Matsuoka K, Go S. Total removal of an intramedullary meningioma of the medulla oblongata-case report. Neurol Med Chir (Tokyo) 1987;27:658-62.

16. Miranda P, Simal JA, Vila M, Hernández M, Menor F, Alvarez-Garijo JA. Posterior fossa clear cell meningioma without dural attachment in a child. Childs Nerv Syst 2009;25:389-92.

17. Teo JG, Goh KY, Rosenblum MK, Muszynski CA, Epstein FJ. Intraparenchymal clear cell meningioma of the brainstem in a 2-year-old child. Case report and literature review. Pediatr Neurosurg 1998;28:27-30.

18. Ishigaki D, Arai H, Sasoh M, Ogasawara K, Uesugi N, Sugai T, et al. Meningioma in the posterior fossa without dural attachment. Neurol Med Chir (Tokyo) 2007;47:364-6.

19. Roşu GC, Pirici I, Stepan AE, Taisescu O, Pătruleasa MC, Mogoantă L, et al. Epithelial-glial transition in an atypical meningioma - a case report. Rom J Morphol Embryol 2019;60:243-48.

20. Kohama I, Sohma T, Nunomura K, Igarashi K, Ishikawa A. Intraparenchymal meningioma in an infant-case report. Neurol Med Chir (Tokyo) 1996;36:598601.

21. Nayil K, Makhdoomi R, Malik R, Ramzan A. Intraparenchymal anaplastic meningioma in a child: A rare entity. Asian J Neurosurg 2015;10:111-3.

22. Louis DN, Ohgaki H, Cavenee WK, et al. World Health Organization (WHO) Classification of tumours of the central nervous system. 4 th revised edition, WHO Classification of Tumours, International Agency for Research on Cancer (IARC) Press, Lyon, France, 2016. p. 232-45.

23. Masalha W, Heiland DH, Franco P, Delev D, Haaker JG, Schnell O, et al. Atypical meningioma: progression-free survival in 161 cases treated at our institution with surgery versus surgery and radiotherapy. J Neurooncol 2018;136:147-54.

24. Cain SA, Smoll NR, Van Heerden J, Tsui A, Drummond KJ. Atypical and malignant meningiomas: Considerations for treatment and efficacy of radiotherapy. J Clin Neurosci 2015;22:1742-8.

25. Wang F, Xu D, Liu Y, Lin Y, Wei Q, Gao Q, et al. Risk factors associated with postoperative recurrence in atypical intracranial meningioma: analysis of 263 cases at a single neurosurgical centre. Acta Neurochir (Wien) 2019;161:2563-70.

\section{Table}


Table 1

Literature summary of well-described cases of complete intraparenchymal meningioma.

\begin{tabular}{|c|c|c|c|c|c|c|c|c|c|c|}
\hline & Author & $\begin{array}{l}\text { Age } \\
\text { (ys.) }\end{array}$ & $\operatorname{sexx}$ & Symptoms & $\begin{array}{l}\text { Location of } \\
\text { Lesion }\end{array}$ & CT & MRI & $\begin{array}{l}\text { Size } \\
(\mathrm{mm})\end{array}$ & $\begin{array}{l}\text { Surgical } \\
\text { resection }\end{array}$ & C \\
\hline 1 & $\begin{array}{l}\text { Zhang, et } \\
\text { al., } 2007^{2}\end{array}$ & 16 & M & epileptic seizure & $\begin{array}{l}\text { right } \\
\text { parietooccipital } \\
\text { region }\end{array}$ & not stated & $\begin{array}{l}\text { T1.,isointense; T2.,hyperintense; } \\
\text { heterogenous enhancement }\end{array}$ & $\begin{array}{l}25 x \\
23\end{array}$ & Total & $\mathrm{N}$ \\
\hline 2 & $\begin{array}{l}\text { Reynolds, } \\
\text { et al., } \\
2016^{3}\end{array}$ & 15 & M & $\begin{array}{l}\text { right knee pain, } \\
\text { weakness and } \\
\text { ataxic gait }\end{array}$ & $\begin{array}{l}\text { left basal } \\
\text { ganglia }\end{array}$ & $\begin{array}{l}\text { a large, } \\
\text { densely } \\
\text { calcified } \\
\text { mass }\end{array}$ & $\begin{array}{l}\text { T1.,isointense; T2.,hyperintense; } \\
\text { heterogenous enhancement }\end{array}$ & $\begin{array}{l}\text { not } \\
\text { stated }\end{array}$ & Subtotal & $\begin{array}{l}\text { ri } \\
\text { hi } \\
\text { a } \\
\text { e: } \\
\text { a }\end{array}$ \\
\hline 3 & $\begin{array}{l}\text { Jiang, et } \\
\text { al., } 2012^{4}\end{array}$ & 23 & M & $\begin{array}{l}\text { nerve palsy and } \\
\text { dysphasia }\end{array}$ & $\begin{array}{l}\text { in the } \\
\text { brainstem, } \\
\text { pons and right } \\
\text { cerebral } \\
\text { peduncle }\end{array}$ & not stated & $\begin{array}{l}\text { T1.,isointense; T2.,isointense; } \\
\text { homogeneous enhancement }\end{array}$ & $\begin{array}{l}35 x \\
25 x \\
20\end{array}$ & Total & $\mathrm{N}$ \\
\hline 4 & $\begin{array}{l}\text { Liu, et al., } \\
2018^{5}\end{array}$ & 8 & M & $\begin{array}{l}\text { headache and } \\
\text { vomiting }\end{array}$ & $\begin{array}{l}\text { right basal } \\
\text { ganglia } \\
\text { extending to } \\
\text { superasellar } \\
\text { cistern }\end{array}$ & $\begin{array}{l}\text { an isodense- } \\
\text { to hyperdense } \\
\text { lesion }\end{array}$ & $\begin{array}{l}\text { T1., isointense; T2., isointense; } \\
\text { inhomogeneous enhancement }\end{array}$ & $\begin{array}{l}40 \times \\
44\end{array}$ & Subtotal & $\begin{array}{l}\text { in } \\
\text { vi } \\
\text { W } \\
\text { CI } \\
\text { lii }\end{array}$ \\
\hline 5 & $\begin{array}{l}\text { Karadereler, } \\
\text { et al., } \\
2004^{6}\end{array}$ & 14 & M & $\begin{array}{l}\text { headache and } \\
\text { seizure }\end{array}$ & $\begin{array}{l}\text { right temporal } \\
\text { region }\end{array}$ & not stated & $\begin{array}{l}\text { T1.,slightly hypointense; T2., } \\
\text { hyperintense; heterogenous } \\
\text { enhancement }\end{array}$ & $\begin{array}{l}15 \times \\
15\end{array}$ & Total & $\mathrm{N}$ \\
\hline 6 & $\begin{array}{l}\text { Shimbo, et } \\
\text { al., } 2011^{7}\end{array}$ & 10 & M & $\begin{array}{l}\text { vomiting, fever } \\
\text { and seizure }\end{array}$ & left frontal lobe & $\begin{array}{l}\text { an isodense } \\
\text { mass lesion, } \\
\text { with } \\
\text { homogeneous } \\
\text { enhancement } \\
\text { by contrast } \\
\text { medium }\end{array}$ & $\begin{array}{l}\text { T1., isointense to hypointense; } \\
\text { T2., isointense; homogeneous } \\
\text { enhancement }\end{array}$ & $\begin{array}{l}20 \times \\
22\end{array}$ & Total & $\mathrm{N}$ \\
\hline 7 & $\begin{array}{l}\text { Werbrouck, } \\
\text { et al., } \\
2014^{8}\end{array}$ & 13 & M & $\begin{array}{l}\text { loss of } \\
\text { consciousness } \\
\text { and generalized } \\
\text { convulsions }\end{array}$ & $\begin{array}{l}\text { right temporal } \\
\text { lobe }\end{array}$ & $\begin{array}{l}\text { a mild } \\
\text { hyperdense } \\
\text { lesion }\end{array}$ & $\begin{array}{l}\text { T2., } \\
\text { heterogeneous hypointense; } \\
\text { T1,homogeneous enhancement }\end{array}$ & $\begin{array}{l}15 \times \\
18 \times \\
34\end{array}$ & Total & $\mathrm{N}$ \\
\hline 8 & $\begin{array}{l}\text { Legius, et } \\
\text { al., } 1985^{9}\end{array}$ & $\begin{array}{l}\text { 14- } \\
\text { month }\end{array}$ & M & $\begin{array}{l}\text { right sided } \\
\text { hemiconvulsions }\end{array}$ & left hemisphere & $\begin{array}{l}\text { a hyperdense } \\
\text { lesion, } \\
\text { enhanced by } \\
\text { contrast } \\
\text { medium }\end{array}$ & Not stated & $\begin{array}{l}20 \times \\
20\end{array}$ & Total & $\mathrm{N}$ \\
\hline 9 & $\begin{array}{l}\text { Tekkök, et } \\
\text { al., } 2005^{10}\end{array}$ & 54 & $\mathrm{~F}$ & $\begin{array}{l}\text { headache and } \\
\text { nausea }\end{array}$ & $\begin{array}{l}\text { right temporal } \\
\text { lobe }\end{array}$ & $\begin{array}{l}\text { an enhancing } \\
\text { intra-axial } \\
\text { mass }\end{array}$ & T1., isointense; T2., isointense & $\begin{array}{l}\text { not } \\
\text { stated }\end{array}$ & Total & $\mathrm{N}$ \\
\hline 10 & $\begin{array}{l}\text { Jadik, et } \\
\text { al., } 2014^{11}\end{array}$ & 42 & M & seizure & $\begin{array}{l}\text { right parietal } \\
\text { lobe }\end{array}$ & $\begin{array}{l}\text { a hyperdense } \\
\text { lesion with } \\
\text { calcification }\end{array}$ & $\begin{array}{l}\text { T1.,hypointense; T2.,mixed hypo- } \\
\text { and hyperintense }\end{array}$ & $\begin{array}{l}15 \times \\
15\end{array}$ & Total & $\mathrm{N}$ \\
\hline 11 & $\begin{array}{l}\text { Zhao, et al., } \\
2011^{12}\end{array}$ & 42 & M & $\begin{array}{l}\text { headache and } \\
\text { dizziness }\end{array}$ & $\begin{array}{l}\text { left temporal } \\
\text { lobe }\end{array}$ & not stated & $\begin{array}{l}\text { solid component: T1., } \\
\text { homogeneous enhancement; } \\
\text { T2.,low intensity }\end{array}$ & $\begin{array}{l}\text { not } \\
\text { stated }\end{array}$ & Total & $\mathrm{N}$ \\
\hline 12 & $\begin{array}{l}\text { Mut, et al., } \\
2000^{13}\end{array}$ & 20 & $\mathrm{~F}$ & $\begin{array}{l}\text { temporal-type } \\
\text { seizures }\end{array}$ & $\begin{array}{l}\text { right temporal } \\
\text { lobe }\end{array}$ & not stated & $\begin{array}{l}\text { T1.,hypointense; } \\
\text { T2.,hyperintense }\end{array}$ & $\begin{array}{l}\text { not } \\
\text { stated }\end{array}$ & Total & $\mathrm{N}$ \\
\hline 13 & $\begin{array}{l}\text { Matsuda,et } \\
\text { al., } 2019^{14}\end{array}$ & 66 & $\mathrm{~F}$ & none & $\begin{array}{l}\text { right basal } \\
\text { ganglia }\end{array}$ & $\begin{array}{l}\text { a small lesion } \\
\text { with tiny } \\
\text { calcifications }\end{array}$ & T1.,homogeneous enhancement ; & $\begin{array}{l}\text { not } \\
\text { stated }\end{array}$ & Biopsy & $\begin{array}{l}\text { n! } \\
\text { di }\end{array}$ \\
\hline 14 & $\begin{array}{l}\text { Sakaki, et } \\
\text { al., } 1987^{15}\end{array}$ & 12 & M & not stated & $\begin{array}{l}\text { one in the right } \\
\text { frontal } \\
\text { parasagittal } \\
\text { region, another } \\
\text { in the region of } \\
\text { the foramen } \\
\text { magnum }\end{array}$ & $\begin{array}{l}\text { high density } \\
\text { lesions with } \\
\text { homogeneous } \\
\text { enhancement }\end{array}$ & not stated & $\begin{array}{l}17 x \\
13\end{array}$ & Total & $\mathrm{N}$ \\
\hline 15 & $\begin{array}{l}\text { Miranda, et } \\
\text { al., } 2009^{16}\end{array}$ & 10 & $\mathrm{~F}$ & $\begin{array}{l}\text { neck pain, right } \\
\text { hemiparesis, gait } \\
\text { instability and } \\
\text { somnolence. }\end{array}$ & $\begin{array}{l}\text { right side of } \\
\text { the } \\
\text { craniocervical } \\
\text { junction }\end{array}$ & enhancement & $\begin{array}{l}\text { T1, intense contrast } \\
\text { enhancement }\end{array}$ & $\begin{array}{l}40 \times \\
35 \times \\
45\end{array}$ & Total & $\mathrm{N}$ \\
\hline
\end{tabular}




\begin{tabular}{|c|c|c|c|c|c|c|c|c|c|c|}
\hline & Author & $\begin{array}{l}\text { Age } \\
\text { (ys.) }\end{array}$ & $\operatorname{sex} x$ & Symptoms & $\begin{array}{l}\text { Location of } \\
\text { Lesion }\end{array}$ & CT & MRI & $\begin{array}{l}\text { Size } \\
(\mathrm{mm})\end{array}$ & $\begin{array}{l}\text { Surgical } \\
\text { resection }\end{array}$ & C \\
\hline 16 & $\begin{array}{l}\text { Present } \\
\text { case }\end{array}$ & 38 & $\mathrm{~F}$ & $\begin{array}{l}\text { neck and } \\
\text { occipital } \\
\text { pain,vomiting, } \\
\text { dizziness }\end{array}$ & $\begin{array}{l}\text { left side of the } \\
\text { medulla } \\
\text { oblongata }\end{array}$ & $\begin{array}{l}\text { no obvious } \\
\text { lesion }\end{array}$ & $\begin{array}{l}\text { T1.,hypointense;T2.,hyperintense; } \\
\text { inhomogeneous enhancement ; }\end{array}$ & $15 \times 9$ & Total & $\mathrm{N}$ \\
\hline
\end{tabular}

\section{Figures}
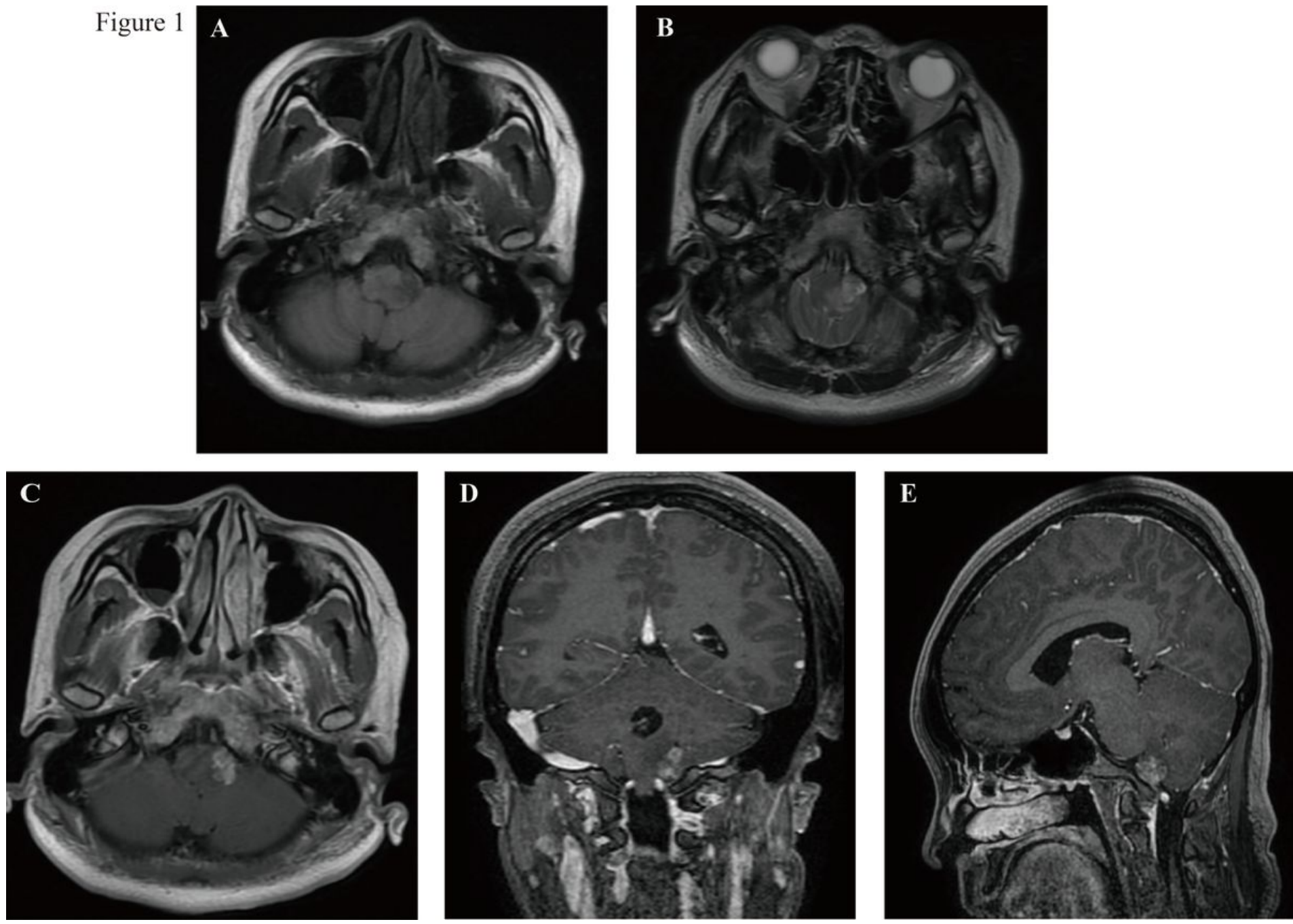

Figure 1

Magnetic resonance imaging of the left side of the medulla oblongata lesion. Axial sections from a non-contrast head MR imaging demonstrate the presence of a $1.5 \times 0.9 \mathrm{~cm}$ mass lesion, located in the left side of the medulla oblongata. The lesion was hypointense on T1-weighted and hyperintense on T2-weighted images (A-B), inhomogeneous enhancement following Gd-DTPA administration (C) axial, (D) coronal and (E) sagittal reconstructions. 
Figure 2
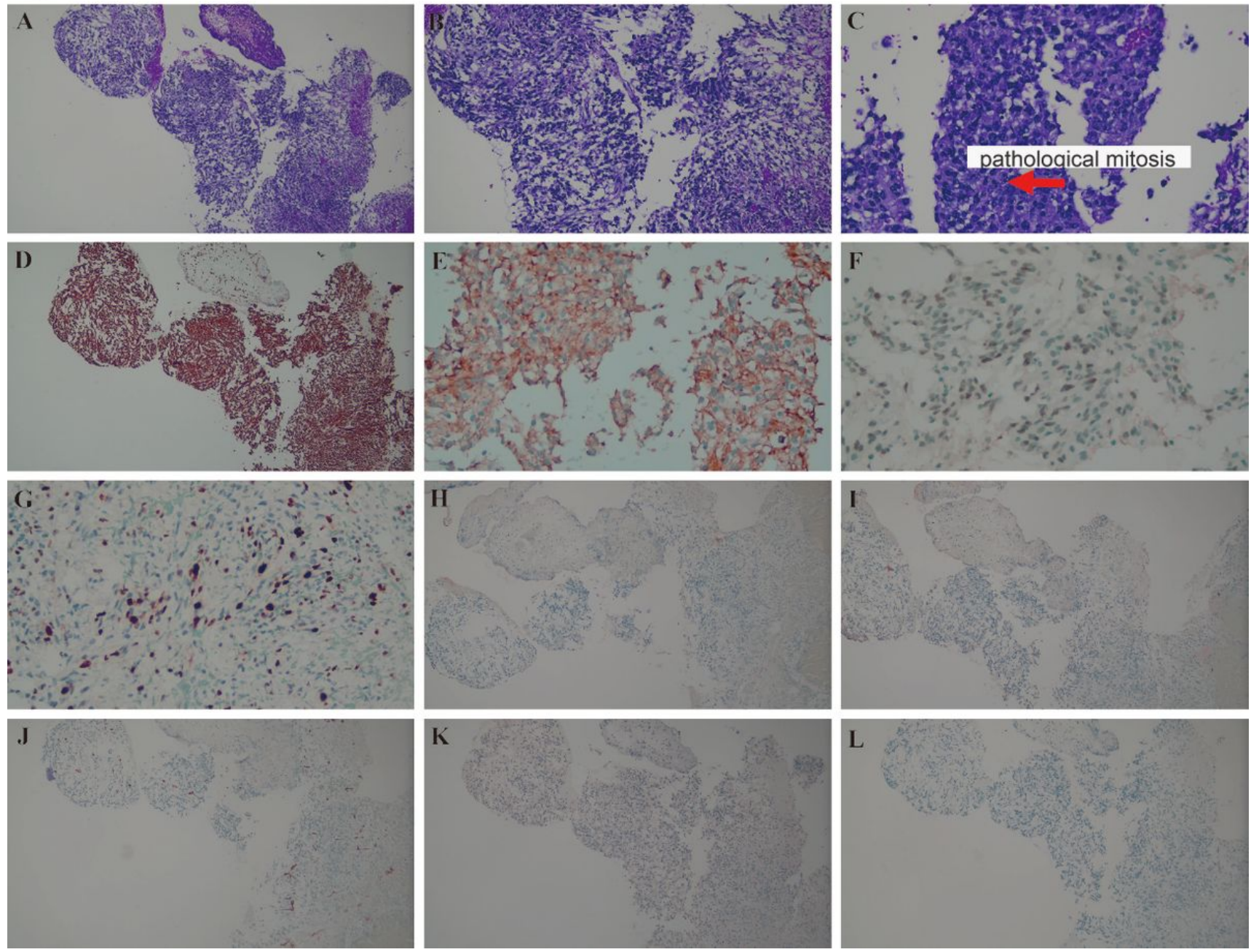

\section{Figure 2}

Hematoxylin-eosin staining exhibiting nests of tumor cell growth, with active proliferation, moderate atypia, some necrosis, and pathological mitosis (A: $\times 100$; B: $\times 200 ; C: \times 400)$. Immunohistochemical staining showing positivity for Vimentin, EMA and PR (D: $\times 100 ; E-F: \times 400)$, but negativity for GFAP, S100, CD34, PAX-8 and the CD56 protein (H-L: $\times 100)$. The Ki-67 labeling index was approximately $30 \%(G: \times 400)$. 
Figure 3
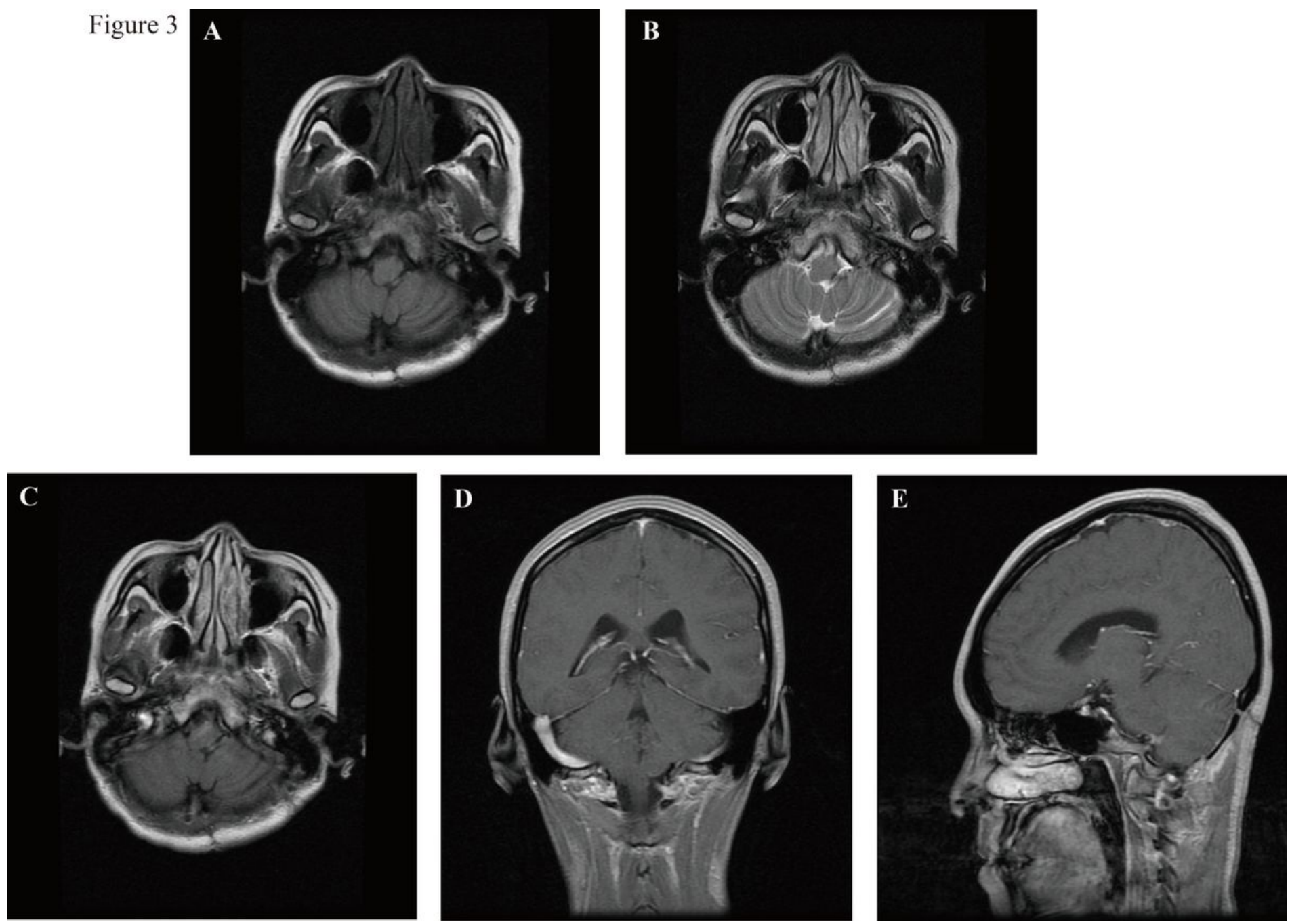

\section{Figure 3}

Postoperative MR imaging. Axial T1-weighted and T2-weighted imaging (A-B), enhancement following Gd-DTPA administration (C) axial, (D) coronal and (E) sagittal reconstructions.

\section{Supplementary Files}

This is a list of supplementary files associated with this preprint. Click to download.

- CAREchecklistEnglish20131.pdf 